\title{
Immunogenicity of botulinum toxin
}

\author{
Syeo Young Wee ${ }^{1}$, Eun Soo Park ${ }^{2}$ \\ ${ }^{1}$ Department of Plastic and Reconstructive Surgery, Soonchunhyang University Gumi Hospital, Gumi; ${ }^{2}$ Department of Plastic and \\ Reconstructive Surgery, Soonchunhyang University Bucheon Hospital, Bucheon, Korea
}

\begin{abstract}
Botulinum toxin treatment is the most common non-surgical cosmetic treatment. Although there are many available treatments using botulinum toxin, their effects are temporary and repeated injections are required. These frequent injections can trigger an immunological response. In addition, botulinum toxin acts as an antigen in the body; thus, its effect disappears progressively due to this immunological reaction, which may cause treatment failure. Active botulinum toxin consists of a core neurotoxin and complexing proteins, the exact effects of which remain unclear. However, the complexing proteins are closely related to the immune response and the formation of neutralizing antibodies. Since neutralizing antibodies can lead to treatment failure, their formation should be prevented. Furthermore, various methods of detecting neutralizing antibodies have been used to predict treatment failure.
\end{abstract}

Keywords Botulinum toxin / Immunogenicity / Treatment failure

\author{
Correspondence: Eun Soo Park \\ Department of Plastic and \\ Reconstructive Surgery, \\ Soonchunhyang Bucheon Hospital, \\ 170 Jomaru-ro, Wonmi-gu, Bucheon \\ 14584, Korea \\ Tel: +82-32-621-5319 \\ Fax: +82-32-621-5016 \\ E-mail: peunsoo@schmc.ac.kr
}

Received: April 11, 2021 - Revised: November 3, 2021 - Accepted: November 7, 2021

pISSN: 2234-6163 • elSSN: 2234-6171 • https://doi.org/10.5999/aps.2021.00766• Arch Plast Surg 2022;49:12-18

\section{INTRODUCTION}

Botulinum toxin is one of the most common non-surgical therapeutic agents in plastic surgery [1]. The most commonly used botulinum toxin product is botulinum toxin type $\mathrm{A}$, which is the first introduced and most widely known toxin serotype approved for cosmetic and clinical purposes [2]. The botulinum toxin type A products used in Korea are onabotulinumtoxin A (Botox; Allergan Inc., Dublin, Ireland), abobotulinumtoxin A (Dysport; Ipsen Ltd., Wrexham, UK), incobotulinumtoxin A (Xeomin; Merz Pharmaceuticals GmbH, Frankfurt am Main, Germany), and BTXA (Lanzhou Institute of Biological Products, Chengguan, China). Among these, onabotulinumtoxin A (Botox) was first approved for commercialization in 2002 and targeted glabellar frown lines [3]. Other products currently approved by the Ministry of Food and Drug Safety in South Korea include Botulax (Hugel, Seoul, Korea), Nabota (Daewoong Pharmaceutical Co. Ltd., Seoul, Korea), Liztox (Huons Global,
Seongnam, Korea), and Wondertox (Chong Kun Dang Pharmaceutical Co., Seoul, Korea), Babitox (Humedix Co., Seongnam, Korea), Rientox (PharmaResearch Bio Co., Gangneung, Korea), Hitox (BMI Korea, Uiwang, Korea), and Bienox (BNC Korea, Daegu, Korea) for export purposes. In addition, the only product using botulinum toxin type $B$ is rimabotulinumtoxin $B$ (Myobloc; Solstice Neurosciences Inc., South San Francisco, CA, USA; also called NeuroBloc). However, it is currently not approved for cosmetic purposes because of the limited research on serotype B [3].

Botulinum toxin works in four areas: the neuromuscular junction, autonomic ganglia, postganglionic parasympathetic nerve endings, and sympathetic nerve endings [4]. It weakens striated muscle by interfering with the transmission of alpha motor neurons at the neuromuscular junction [3]. Moreover, it also inhibits the secretion of acetylcholine in parasympathetic and cholinergic postganglionic sympathetic neurons. Thus, it acts as a potential treatment for overactive smooth muscles and abnormally 
active glands [5].

Based on these characteristics, botulinum toxin has been used in cosmetic and clinical fields. In the cosmetic field, it is generally applied to glabellar frown lines, crow's feet, and transverse lines of the forehead [6-12]. Its use in the clinical field was first described for strabismus by Scott in 1977, and it was then used to treat blepharospasm in the early 1980s [13-16]. Botulinum toxin is used medically in movement disorders (spasticity, cervical dystonia, anal fissures, upper extremity dystonia, tremors, and adductor laryngeal dystonia), urological disorders (overactive bladder and urinary incontinence), dermatological conditions (axillary and palm hyperhidrosis), and for pain treatment in myofascial pain syndrome [17-22]. However, these diseases requiring botulinum toxin treatment mainly have a chronic course, and muscle weakness due to botulinum toxin injection has a duration of approximately 3 months. Therefore, most patients require repetitive toxin injections $[3,17]$. Tolerance occurs in patients who receive repeated botulinum toxin treatment, with treatment failure induced by the immune reaction. Therefore, based on the structural characteristics of botulinum toxin, we reviewed treatment failure related to immunogenicity.

\section{STRUCTURAL CHARACTERISTICS OF BOTULINUM TOXIN}

Botulinum toxin is a protein derived from a bacterium known as Clostridium botulinum, an anaerobic, spore-forming, and rodshaped bacterium [17]. Active botulinum toxin is a high-molecular-weight complex composed of $150 \mathrm{kD}$ core neurotoxins and $900 \mathrm{kD}$ complexing proteins, which are known as neurotoxinassociated proteins $[23,24]$.

The core neurotoxin is synthesized as a single polypeptide chain and linked by a disulfide bond, resulting in a bi-chain molecule consisting of a heavy and a light chain [25]. It is attached to the presynaptic membrane before acetylcholine is secreted into the synaptic cleft, thereby preventing the secretion of acetylcholine neurotransmitters at the neuromuscular junction [26-29]. This disruption of acetylcholine exocytosis interferes with the synaptic neural transmission of cholinergic-innervated structures in smooth muscles and other exocrine glands along with striated muscles [30]. Only core neurotoxins have therapeutic effects [17].

The complexing proteins are divided into hemagglutinin (HA) and non-toxic protein and non-hemagglutinin (NTNHA) proteins depending on the presence of HA activity [30-33]. The three HA proteins are HA1 (= HA-33), HA2 (=HA-17), and HA3 ( = HA-70), and HA3 is divided into HA3a and HA3b [34]. Among these, HA-1 (HA-33), which is the largest component of the complexing proteins, is known to be the most important protein for the immunogenicity of botulinum toxin [17].

Botulinum toxin is classified into eight serotypes (A, B, C1, C2, D, E, F, and G) based on its immunological characteristics [3]. Type $A$ is the most potent protein, followed by $B$ and $F$ toxins, and $\mathrm{A}, \mathrm{B}$, and $\mathrm{E}$ are types related to systemic botulism in humans [35]. Of these, only types A and B have been commercialized for clinical use [32]. In these botulinum toxin serotypes, neurotoxins form a toxin complex by non-covalent binding to a complexing protein $[34,36]$.

\section{MOST COMMONLY USED BOTULINUM TOXIN TYPE A PRODUCTS}

Most commercial products have the same botulinum toxin serotype; however, various preparations are made that differ in terms of their composition, the concentration of neurotoxins, and the size of the complexing proteins (Table 1) [37].

The three most common botulinum toxin type A products are

Table 1. Products containing botulinum toxin

\begin{tabular}{|c|c|c|c|c|c|}
\hline Product name & Alternative name & Company & Serotype & Form & Storage \\
\hline Botox & Onabotulinum A & Allergan Inc. & Type A & Powder & $2^{\circ} \mathrm{C}$ to $8^{\circ} \mathrm{C}, 36$ months \\
\hline Dysport & $\begin{array}{l}\text { Abobotulinum A } \\
\text { Reloxin } \\
\text { Azzalure }\end{array}$ & Ipsen Ltd. & Type A & Powder & $2^{\circ} \mathrm{C}$ to $8^{\circ} \mathrm{C}, 24$ months \\
\hline Xeomin & $\begin{array}{l}\text { Incobotulinum A } \\
\text { Biocouture }\end{array}$ & Merz Pharmaceuticals & Type A & Powder & $-20^{\circ} \mathrm{C}$ to $25^{\circ} \mathrm{C}, 36$ months \\
\hline BTXA & $\begin{array}{l}\text { CBTX-A } \\
\text { Prosigne } \\
\text { Lantox } \\
\text { Redux }\end{array}$ & Lanzhou Institute of Biological Products & Type A & Powder & $-20^{\circ} \mathrm{C}$ to $-5^{\circ} \mathrm{C}, 36$ months \\
\hline Myobloc & $\begin{array}{l}\text { Rimabotulinum B } \\
\text { Neurobloc }\end{array}$ & Solstice Neurosciences & Type B & Solution & $2^{\circ} \mathrm{C}$ to $8^{\circ} \mathrm{C}, 36$ months \\
\hline Botulax & Letibotulinum A & Hugel & Type A & Powder & $2^{\circ} \mathrm{C}$ to $8^{\circ} \mathrm{C}, 36$ months \\
\hline Nabota & Prabotulinum A & Daewoong Pharmaceutical Co., Ltd. & Type A & Powder & $2^{\circ} \mathrm{C}$ to $8^{\circ} \mathrm{C}, 36$ months \\
\hline
\end{tabular}


onabotulinumtoxin (Botox), abobotulinumtoxin (Dysport), and incobotulinumtoxin A (Xeomin). When comparing the clinical effects of these three types, onabotulinumtoxin and incobotulinum toxins are known to have a conversion ratio of $1: 1$ [38-40]. In addition, a conversion ratio of 1:2-3 was reported for onabotulinumtoxin and abobotulinumtoxin [38].

These three types of botulinum toxin type A products have similar mechanisms of action, but different manufacturing processes and complexing proteins; therefore, they have different molecular weights and three-dimensional structures $[31,41]$. Unlike onabotulinumtoxin and abobotulinumtoxin, incobotulinumtoxin is composed of only neurotoxins without complexing proteins [42]. However, since only neurotoxins affect the body clinically, these other structures do not affect the botulinum toxin. There is also no difference in diffusion to the target tissue because neurotoxins are already separated from the complexing proteins as they are reconstituted in the vial [43]. However, various botulinum toxin products induce different host immune responses [44].

\section{IMMUNE RESPONSE RELATED TO COMPLEXING PROTEINS}

Complexing proteins play a role in stabilizing and protecting core neurotoxins [30]. However, their role in the preparation of botulinum toxin is currently unclear. Three hypotheses have been proposed to explain complexing proteins.

First, it was established that complexing proteins protect botulinum toxin in the gastrointestinal tract [45]. Biochemical analyses have reported that this protection manifests as protease resistance in other toxin types [46]. However, therapeutically, botulinum toxin type A is not delivered orally; thus, the complexing proteins' protective role against gastric acidity is not clinically relevant [47].

Second, complexing proteins stabilize biological activity during the pre-use period of neurotoxins and help bind to muscles when used [48]. However, the stability of incobotulinumtoxin A (Xeomin), which does not contain a complexing protein, has been found in long-term storage studies [47,49].

Third, the complexing protein is large, thereby limiting the diffusion of botulinum toxin from the target tissue [50]. However, previous in vivo and radiolabeling studies found no differences in the spread after injection between various botulinum toxin type A preparations [51,52].

Instead, complexing proteins are known to be involved in immunostimulation as potential stimulating factors for immune cells [53]. In this regard, it has been established that complexing proteins are related to the interleukin (IL)-6 pathway and stimu- late an immune response by inducing the secretion of inflammatory cytokines [32]. This is remarkable since an increase in transforming growth factor-beta 1 , an inflammation-related marker, is observed with IL-6 after intramuscular injections of botulinum toxin $[54,55]$. According to previous studies of human neuroblastoma cells, the botulinum toxin product with complexing protein acts on lymphoblasts and fibroblasts in addition to neuronal cells and stimulates the release of multiple inflammatory cytokines [56].

\section{GENERATION OF NEUTRALIZING ANTIBODIES}

Immunogenicity refers to antibody formation by protein products, and botulinum toxin is not exempt from this phenomenon [44]. The proteins in botulinum toxin act as antigens, causing an immune response that stimulates the formation of antibodies [44]. Antibodies that block the effect of botulinum toxin are called neutralizing (blocking) antibodies, which are related to only the neurotoxin [17]. Instead, antibodies that do not have clinically relevant effects are called on-neutralizing antibodies, and these are related to complexing proteins [17].

Antigenicity depends on the amount of protein; hence, a high amount of protein in a botulinum toxin formulation increases the formation of neutralizing antibodies [57-59]. In this regard, the antigenic protein load, which considers the amount of neurotoxin and complexing protein, rather than only the neurotoxin protein amount, is reflected in the generation of neutralizing antibodies [32]. This means that the presence of complexing proteins of botulinum toxin increases the antigenic protein load and is a risk factor for the formulation of neutralizing antibodies [47], which leads to treatment failure [24].

\section{ADVERSE RESPONSES ASSOCIATED WITH COMPLEXING PROTEINS}

Treatment failure (non-response) reflects the patient's and/or the physician's lack of satisfaction with the outcome of treatment, implying that the treatment is partially or completely ineffective [17].

Treatment failure is classified as primary and secondary [17]. Primary failure is defined as less than a 25\% response despite an increase in dose or 2-3 trials of injections [27]. This can be caused by low sensitivity to botulinum toxin, misdiagnosis, an insufficient dose, and incorrect injection into other muscles [60]. Secondary failure is observed when the toxin is effective at the first injection but has no effect afterward. This is due to the placebo effect or deterioration of the disease, indicating a poor 
prognosis [17]. The presence of neutralizing antibodies and immunogenic proteins is another important factor [61].

The injection session dose, injection interval, cumulative dose, number of injections, previous injection history, and botulinum toxin formulation may affect immunogenicity as treatment-related causes of the immune response $[44,62,63]$. Specifically, single and cumulative doses of treatment and botulinum toxin formulation have been reported to induce the development of neutralizing antibodies [62]. In a comparison of the three most common botulinum toxins of serotype A, it was reported that abobotulinumtoxin was associated with the most development of neutralizing antibodies, followed by incobotulinumtoxin, and onabotulinumtoxin was associated with the lowest incidence [64].

Hypersensitivity might also occur as a rare adverse event after botulinum toxin injection [65]. This event is inferred to be caused by a protein component formed by a combination of a complexing protein and a gelatin component used as a pharmaceutical solvent in botulinum toxin preparation [65]. Further, immunoglobulin E-mediated anaphylaxis has been reported after botulinum toxin injection [66].

However, lower doses are generally used for aesthetic indications than for therapeutic indications, and a pivotal clinical study on aesthetic indication reported no treatment failure due to antibody development $[67,68]$.

\section{ATTEMPTS TO PREVENT AND OVERCOME TREATMENT FAILURE}

Previous attempts to prevent and overcome antibody-induced treatment failure have yielded limited results. The cause of treatment failure has not been identified; however, it can be explained by an increase in the antibody response [69].

To overcome treatment failure, attempts have been made to replace the serotype of botulinum toxin with other types, although the results are limited. The formation of antibodies against botulinum toxin is sero-specific [27]. However, when type $B$ was injected in patients with cervical dystonia resistant to botulinum toxin type A, most of them showed a temporary effect but eventually experienced treatment failure [70]. Furthermore, cross-reactivity between the two toxin serotypes resulted in rapid immune resistance [69]. Plasmapheresis or intravenous immunoglobulin can also remove neutralizing antibodies; however, these treatments incur high risks and costs $[60,71]$.

Therefore, to reduce antigen occurrence, a product with a low risk of antigenicity should be selected. To minimize the risk of neutralizing antibody formation, it is recommended to use the product at the minimum dose, avoid additional booster injec- tions, reduce the single injection dose, and perform injections at intervals of at least 3 months $[44,62]$.

\section{TOOLS TO DETECT NEUTRALIZING ANTIBODIES}

Accurate detection of neutralizing antibodies is important for detecting treatment failure. When the treatment effect of botulinum toxin diminishes, the formation of neutralizing antibodies is suspected after excluding other causes of treatment failure. Similarly, laboratory assays are required to detect antibodies.

Laboratory assays can be divided into structural assays and bioassays. Structural assays, such as enzyme-linked immunosorbent assays, fluorescence immunoassays, and immunoprecipitation assays, are sensitive for antibody detection and are mainly used as screening tests $[17,33]$. However, these methods cannot differentiate between neutralizing and non-neutralizing antibodies. Therefore, bioassays such as the mouse protection assay (MPA) and mouse hemidiaphragm assay (MHDA) are used to identify neutralizing antibodies in animals. The MPA may not be an ideal assay because it requires animal sacrifice in clinical use, takes a substantial amount of time, is expensive, and requires a specialized laboratory $[33,60]$. In addition, the MPA has $100 \%$ specificity, but its sensitivity is relatively low (less than $50 \%$ ) [72]. On the contrary, MHDA has high sensitivity, requires fewer animals, and requires less cost and time. However, it has a disadvantage in predicting treatment failure because the number of false positives may also be high due to its high sensitivity $[33,60]$.

Clinical tests are becoming easier to implement. The unilateral brow injection test is a valuable method of screening for treatment failure [27]. Similarly, the frontalis antibody test is used to measure the asymmetry of forehead wrinkles through injection into the frontalis muscle [72]. The extensor digitorum brevis test to check the action potential of extensor digitorum brevis muscles, the sternocleidomastoid muscle test to check the maximal contraction of the sternocleidomastoid muscle, and the ninhydrin sweat test to check sweat production are also being used [73-75].

\section{CONCLUSION}

Treatment with botulinum toxin requires repeated injections in various cosmetic and clinical settings. An important cause of secondary treatment failure is the immune response caused by the occurrence of neutralizing antibodies. Therefore, based on these findings, there is a need for new botulinum toxin products with a lower antigenic protein load to reduce the formation of 
neutralizing antibodies that can be applied in minimal amounts without frequent injections to minimize factors related to immunogenicity. In addition, the development of an ideal tool that can detect neutralizing antibodies easily and accurately is required.

\section{NOTES}

\section{Conflict of interest}

No potential conflict of interest relevant to this article was reported.

\section{Author contribution}

Conceptualization: ES Park. Writing - original draft: SY Wee. Writing - review \& editing: ES Park, SY Wee. All authors read and approved the final manuscript.

\section{ORCID}

Syeo Young Wee https://orcid.org/0000-0002-1787-9715

Eun Soo Park https://orcid.org/0000-0003-2966-9122

\section{REFERENCES}

1. Garcia A, Fulton JE Jr. Cosmetic denervation of the muscles of facial expression with botulinum toxin: a dose-response study. Dermatol Surg 1996;22:39-43.

2. Tsui JK. Botulinum toxin as a therapeutic agent. Pharmacol Ther 1996;72:13-24.

3. Nigam PK, Nigam A. Botulinum toxin. Indian J Dermatol 2010;55:8-14.

4. Sellin LC. The pharmacological mechanism of botulism. Trends Pharmacol Sci 1985;6:80-2.

5. Munchau A, Bhatia KP. Uses of botulinum toxin injection in medicine today. BMJ 2000;320:161-5.

6. Jankovic J. Botulinum toxin in clinical practice. J Neurol Neurosurg Psychiatry 2004;75:951-7.

7. Guida S, Farnetani F, Nistico SP, et al. New trends in botulinum toxin use in dermatology. Dermatol Pract Concept 2018;8:277-82.

8. Harii K, Kawashima M. A double-blind, randomized, placebo-controlled, two-dose comparative study of botulinum toxin type A for treating glabellar lines in Japanese subjects. Aesthetic Plast Surg 2008;32:724-30.

9. Honeck P, Weiss C, Sterry W, et al. Reproducibility of a fourpoint clinical severity score for glabellar frown lines. $\mathrm{Br} \mathrm{J}$ Dermatol 2003;149:306-10.

10. Carruthers JD, Lowe NJ, Menter MA, et al. Double-blind, placebo-controlled study of the safety and efficacy of botuli- num toxin type A for patients with glabellar lines. Plast Reconstr Surg 2003;112:1089-98.

11. Won CH, Lee HM, Lee WS, et al. Efficacy and safety of a novel botulinum toxin type A product for the treatment of moderate to severe glabellar lines: a randomized, doubleblind, active-controlled multicenter study. Dermatol Surg 2013;39(1 Pt 2):171-8.

12. Won $\mathrm{CH}$, Kim HK, Kim BJ, et al. Comparative trial of a novel botulinum neurotoxin type A versus onabotulinumtoxin $A$ in the treatment of glabellar lines: a multicenter, randomized, double-blind, active-controlled study. Int J Dermatol 2015;54:227-34.

13. Scott AB. Botulinum toxin injection of eye muscles to correct strabismus. Trans Am Ophthalmol Soc 1981;79:73470.

14. Dressler D. Complete secondary botulinum toxin therapy failure in blepharospasm. J Neurol 2000;247:809-10.

15. Scott AB, Kennedy RA, Stubbs HA. Botulinum A toxin injection as a treatment for blepharospasm. Arch Ophthalmol 1985;103:347-50.

16. Frueh BR, Felt DP, Wojno TH, et al. Treatment of blepharospasm with botulinum toxin: a preliminary report. Arch Ophthalmol 1984;102:1464-8.

17. Benecke R. Clinical relevance of botulinum toxin immunogenicity. BioDrugs 2012;26:e1-9.

18. Hsieh PF, Chiu HC, Chen KC, et al. Botulinum toxin A for the treatment of overactive bladder. Toxins (Basel) 2016;8: 59.

19. Dat A, Chin M, Skinner S, et al. Botulinum toxin therapy for chronic anal fissures: where are we at currently? ANZ J Surg 2017;87:E70-3.

20. Camargo CH, Cattai L, Teive HA. Pain relief in cervical dystonia with botulinum toxin treatment. Toxins (Basel) 2015; 7:2321-35.

21. Bhidayasiri R, Truong DD. Evidence for effectiveness of botulinum toxin for hyperhidrosis. J Neural Transm (Vienna) $2008 ; 115: 641-5$.

22. Ferrante FM, Bearn L, Rothrock R, et al. Evidence against trigger point injection technique for the treatment of cervicothoracic myofascial pain with botulinum toxin type A. Anesthesiology 2005;103:377-83.

23. Inoue K, Fujinaga Y, Watanabe T, et al. Molecular composition of Clostridium botulinum type A progenitor toxins. Infect Immun 1996;64:1589-94.

24. Sharma SK, Singh BR. Immunological properties of Hn-33 purified from type A Clostridium botulinum. J Nat Toxins 2000;9:357-62.

25. Kukreja RV, Singh BR. Comparative role of neurotoxin-as- 
sociated proteins in the structural stability and endopeptidase activity of botulinum neurotoxin complex types A and E. Biochemistry 2007;46:14316-24.

26. Kwak S, Kang WH, Rhee $\mathrm{CH}$, et al. Comparative pharmacodynamics study of 3 different botulinum toxin type A preparations in mice. Dermatol Surg 2020;46:e132-8.

27. Bellows S, Jankovic J. Immunogenicity associated with botulinum toxin treatment. Toxins (Basel) 2019;11:491.

28. Dong M, Yeh F, Tepp WH, et al. SV2 is the protein receptor for botulinum neurotoxin A. Science 2006;312:592-6.

29. Pirazzini M, Rossetto O, Eleopra R, et al. Botulinum neurotoxins: biology, pharmacology, and toxicology. Pharmacol Rev 2017;69:200-35.

30. Dressler D, Bigalke H. Immunological aspects of botulinum toxin therapy. Expert Rev Neurother 2017;17:487-94.

31. Stanley EF, Drachman DB. Botulinum toxin blocks quantal but not non-quantal release of $\mathrm{ACh}$ at the neuromuscular junction. Brain Res 1983;261:172-5.

32. Kukreja R, Chang TW, Cai S, et al. Immunological characterization of the subunits of type A botulinum neurotoxin and different components of its associated proteins. Toxicon 2009;53:616-24.

33. Naumann M, Boo LM, Ackerman AH, et al. Immunogenicity of botulinum toxins. J Neural Transm (Vienna) 2013; 120:275-90.

34. Hasegawa K, Watanabe T, Suzuki T, et al. A novel subunit structure of Clostridium botulinum serotype D toxin complex with three extended arms. J Biol Chem 2007;282: 24777-83.

35. Ellenhorn MJ, Barceloux DG. Medical toxicology: diagnosis and treatment of human poisoning. New York: Elsevier; 1988. p. 1185-7.

36. Fujinaga Y. Transport of bacterial toxins into target cells: pathways followed by cholera toxin and botulinum progenitor toxin. J Biochem 2006;140:155-60.

37. Park JY, Sunga O, Wanitphakdeedecha R, et al. Neurotoxin impurities: a review of threats to efficacy. Plast Reconstr Surg Glob Open 2020;8:e2627.

38. Ravenni R, De Grandis D, Mazza A. Conversion ratio between Dysport and Botox in clinical practice: an overview of available evidence. Neurol Sci 2013;34:1043-8.

39. Carruthers J, Fournier N, Kerscher M, et al. The convergence of medicine and neurotoxins: a focus on botulinum toxin type $\mathrm{A}$ and its application in aesthetic medicine: a global, evidence-based botulinum toxin consensus education initiative. Part II: incorporating botulinum toxin into aesthetic clinical practice. Dermatol Surg 2013;39(3 Pt 2): 510-25.
40. Lorenc ZP, Kenkel JM, Fagien S, et al. Consensus panel's assessment and recommendations on the use of 3 botulinum toxin type A products in facial aesthetics. Aesthet Surg J 2013;33(1 Suppl):35S-40S.

41. Krebs KM, Lebeda FJ. Comparison of the structural features of botulinum neurotoxin and NTNH, a non-toxic accessory protein of the progenitor complex. Botulinum J 2008:1:11634.

42. Frevert J. Content of botulinum neurotoxin in Botox ${ }^{\circledR} /$ Vistabel $^{\circledR}$, Dysport ${ }^{\circledR} /$ Azzalure $^{\circledR}$, and Xeomin ${ }^{\circledR} /$ Bocouture $^{\circledR}$. Drugs RD 2010;10:67-73.

43. Kerscher M, Roll S, Becker A, et al. Comparison of the spread of three botulinum toxin type A preparations. Arch Dermatol Res 2012;304:155-61.

44. Frevert J. Pharmaceutical, biological, and clinical properties of botulinum neurotoxin type A products. Drugs R D 2015; 15:1-9.

45. Ohishi I, Sugii S, Sakaguchi G. Oral toxicities of Clostridium botulinum toxins in response to molecular size. Infect Immun 1977; 16:107-9.

46. Chen F, Kuziemko GM, Stevens RC. Biophysical characterization of the stability of the 150-kilodalton botulinum toxin, the nontoxic component, and the 900-kilodalton botulinum toxin complex species. Infect Immun 1998;66:2420-5.

47. Frevert J, Dressler D. Complexing proteins in botulinum toxin type A drugs: a help or a hindrance? Biologics 2010;4:32532.

48. Johnson EA, Bradshaw M. Clostridium botulinum and its neurotoxins: a metabolic and cellular perspective. Toxicon 2001;39:1703-22.

49. Grein S, Mander GJ, Taylor HV. Xeomin ${ }^{\circledR}$ is stable without refrigeration: Complexing proteins are not required for stability of botulinum neurotoxin type A preparations. Toxicon 2008;51 Suppl 1:13.

50. de Almeida AT, De Boulle K. Diffusion characteristics of botulinum neurotoxin products and their clinical significance in cosmetic applications. J Cosmet Laser Ther 2007;9 Suppl 1:17-22.

51. Dodd SL, Rowell BA, Vrabas IS, et al. A comparison of the spread of three formulations of botulinum neurotoxin $A$ as determined by effects on muscle function. Eur J Neurol 1998;5:181-6.

52. Tang-Liu DD, Aoki KR, Dolly JO, et al. Intramuscular injection of 125I-botulinum neurotoxin-complex versus 125Ibotulinum-free neurotoxin: time course of tissue distribution. Toxicon 2003;42:461-9.

53. Frevert J. Xeomin is free from complexing proteins. Toxicon 2009;54:697-701. 
54. Pingel J, Nielsen MS, Lauridsen T, et al. Injection of high dose botulinum-toxin A leads to impaired skeletal muscle function and damage of the fibrilar and non-fibrilar structures. Sci Rep 2017;7:14746.

55. Seo MS, Kim YI, Kang KK, et al. Comparison study of the response with botulinum toxin muscle injection in the ICR mice from three different sources. Lab Anim Res 2019;35: 11.

56. Wang L, Sun Y, Yang W, et al. Type A botulinum neurotoxin complex proteins differentially modulate host response of neuronal cells. Toxicon 2014;82:52-60.

57. Goschel H, Wohlfarth K, Frevert J, et al. Botulinum A toxin therapy: neutralizing and nonneutralizing antibodies. Therapeutic consequences. Exp Neurol 1997;147:96-102.

58. Sankhla C, Jankovic J, Duane D. Variability of the immunologic and clinical response in dystonic patients immunoresistant to botulinum toxin injections. Mov Disord 1998;13: 150-4.

59. Dressler D, Bigalke H. Botulinum toxin antibody type A titres after cessation of botulinum toxin therapy. Mov Disord 2002;17:170-3.

60. Dressler D. Clinical presentation and management of antibody-induced failure of botulinum toxin therapy. Mov Disord 2004;19 Suppl 8:S92-100.

61. Kromminga A, Schellekens H. Antibodies against erythropoietin and other protein-based therapeutics: an overview. Ann N Y Acad Sci 2005; 1050:257-65.

62. Albrecht P, Jansen A, Lee JI, et al. High prevalence of neutralizing antibodies after long-term botulinum neurotoxin therapy. Neurology 2019;92:e48-54.

63. Naumann M, Carruthers A, Carruthers J, et al. Meta-analysis of neutralizing antibody conversion with onabotulinumtoxinA $\left(\mathrm{BOTOX}^{\circledR}\right)$ across multiple indications. Mov Disord 2010;25:2211-8.

64. Rahman E, Alhitmi HK, Mosahebi A. Immunogenicity to botulinum toxin type A: a systematic review with metaanalysis across therapeutic indications. Aesthet Surg J 2022;
42:106-20.

65. Wang C, Sun T, Li H, et al. Hypersensitivity caused by cosmetic injection: systematic review and case report. Aesthetic Plast Surg 2021;45:263-72.

66. Moon IJ, Chang SE, Kim SD. First case of anaphylaxis after botulinum toxin type A injection. Clin Exp Dermatol 2017; 42:760-2.

67. Torres S, Hamilton M, Sanches E, et al. Neutralizing antibodies to botulinum neurotoxin type $\mathrm{A}$ in aesthetic medicine: five case reports. Clin Cosmet Investig Dermatol 2013; 7:11-7.

68. Coleman WP 3rd, Sattler G, Weissenberger P, et al. Safety of incobotulinumtoxinA in the treatment of facial lines: results from a pooled analysis of randomized, prospective, controlled clinical studies. Dermatol Surg 2017;43 Suppl 3: S293-303.

69. Atassi MZ. Basic immunological aspects of botulinum toxin therapy. Mov Disord 2004;19 Suppl 8:S68-84.

70. Dressler D, Bigalke H, Benecke R. Botulinum toxin type B in antibody-induced botulinum toxin type A therapy failure. J Neurol 2003;250:967-9.

71. Dressler D, Zettl U, Benecke R, et al. Can intravenous immunoglobulin improve antibody-mediated botulinum toxin therapy failure? Mov Disord 2000;15:1279-81.

72. Hanna PA, Jankovic J. Mouse bioassay versus Western blot assay for botulinum toxin antibodies: correlation with clinical response. Neurology 1998;50:1624-9.

73. Gordon PH, Gooch CL, Greene PE. Extensor digitorum brevis test and resistance to botulinum toxin type A. Muscle Nerve 2002;26:828-31.

74. Dressler D, Bigalke H, Rothwell JC. The sternocleidomastoid test: an in vivo assay to investigate botulinum toxin antibody formation in humans. J Neurol 2000;247:630-2.

75. Voller B, Moraru E, Auff E, et al. Ninhydrin sweat test: a simple method for detecting antibodies neutralizing botulinum toxin type A. Mov Disord 2004;19:943-7. 